CHAPTER 3

\title{
Incapable and Shallow Innocents Mourning Shakespeare's Children in Richard III and The Winter's Tale Charlotte Scott
}

\author{
Since what I am to say must be but that \\ Which contradicts my accusation and \\ The testimony on my part no other \\ But what comes from myself, it shall scarce boot me \\ To say "not guilty:" mine integrity \\ Being counted falsehood, shall, as I express it, \\ Be so received. But thus: if powers divine \\ Behold our human actions, as they do, \\ I doubt not then but innocence shall make \\ False accusation blush and tyranny \\ Tremble at patience. ${ }^{\mathrm{I}}$
}

As Hermione stands before her accuser and husband, charged with adultery and with carrying an illegitimate child, the concept of innocence resonates throughout the theatrical space. The power that Hermione affords innocence, to make "false accusation blush and tyranny/ Tremble at patience," comes to reside in the bitter irony of Mamillius's death. As the queen stands "not guilty" and supported by "powers divine," two presiding forms of innocence are destroyed - one is her plea and the other is her son. There is perhaps no other play by Shakespeare so preoccupied by the idea of innocence than The Winter's Tale: from the picture of the young kings' childhood as "twinned lambs" frolicking about in the prelapsarian paradise of male company, through the wide-eyed curiosity of Mamillius, to the Sicilian queen's conscience, and finally to the infant Perdita, what it means to be innocent is fundamental to the play-world. ${ }^{2}$ But in a play fascinated by both children and guilt, what does innocence mean? This is the question at the center of this essay and one I explore through both The Winter's Tale and Richard III. ${ }^{3}$ Both plays are dependent upon focal structures of conscience and innocence, which are mediated through the image of the child. 
Additionally, this essay will suggest that the image of the child occupies a crucial space in the plays' renditions of loss. These versions of loss are central to the ideas of narrative and history through which the plays construct their stories. Grieving dead children, losing one's childhood or being rendered in a permanent state of fear collude in these plays to adumbrate a dream of innocence, which can only be accompanied by the child.

To a greater extent, all conceptions of childhood are mediated through hindsight and grief: even adult descriptions of their own children tend to revolve around images or instances of anxiety. ${ }^{4}$ To recover a child's version of childhood, however, is perhaps an elusive task and not one that I am concerned with here: rather, what remains both fascinating and revealing about the idea of childhood is its pivotal role in the adult imagination. Frequently deployed through terms such as innocence or virtue, the concept of childhood is almost always animated by adults in Shakespeare's drama, not children. Grief is central to Shakespeare's conception of both the child and childhood. Whether it is through the actual loss of a young person or the figurative loss of the qualities they embody, innocence and grief come to reside in the adult/child relations that define the moral visions of these plays.

The term "innocent" is most frequently, and perhaps most unthinkingly, applied to children: an emotive marker of purity and virtue, the epithet almost always accompanies the status of the child as victim. In Matthew, for example, when Christ says "Suffer little children, and forbid them not to come unto me: for such is the kingdom of heaven" (I9:I4), the gates of heaven stand ajar for the child as a synecdoche for innocence. The biblical narrative of infanticide, known as the Massacre of the Innocents, alerts us, even at its most basic semantic level, to the profanity of Herod's order. To kill children is to destroy the purest quality that the human can lay claim to. ${ }^{5}$ Yet, as with all such relative terms, the idea of innocence is constantly under construction. ${ }^{6}$ Perhaps two of the most famous enunciations of innocence in Shakespeare's plays are characterized by their ambiguity. When Cesario declares to Olivia that "By innocence / I swear, and by my youth / I have one heart, one bosom and one truth, / And that no woman has; nor never none / Shall mistress be of it, save I alone" the ironic position of the speaker's gender plays havoc with its sincerity. Similarly, when Lady Macbeth tells her husband to "look like the innocent flower, / But be the serpent under it," we are in no doubt as to the questionable nature of the flower's innocence. What both these quotations point to, however, is that innocence is a relational term. Viola 
may herself be innocent (meaning, we assume, both virginal and honest), but dressed as a man seducing a woman, the transparency of her claim is somewhat compromised. Equally, the flower that hides Lady Macbeth's metaphorical serpent may itself be innocent but only to the extent that it must be unaware of the snake beneath it. Innocence, then, is perhaps always relative and never more tragically so than when it is parodied by experience. In Shakespeare's narrative poem The Rape of Lucrece, the heroine is defined by her innocence, yet it is just such a quality that will condemn her to Tarquin's rapacious lust, unable as she is to "read" his intentions. ${ }^{7}$ William Blake would, of course, make the relational nature of these terms famous in his series of poems of "songs" dedicated to the dynamic and unsettling inevitability that innocence will eventually lead to, or be condemned by, experience, such is the pattern of our prelapsarian lives. Indeed, as Milton's narrator observes after the couple has eaten from the Tree of Knowledge, the future of human life is sentenced to perpetually mourn the loss of that once cherished virtue:

\section{Sin-bred, how have ye troubled all mankind \\ With shows instead, mere shows of seeming pure, And banished from man's life his happiest life, \\ Simplicity and spotless innocence}

(Bk. IV: 313-316)

As a cardinal virtue, innocence is destroyed by Adam's uxoriousness and can now only ever manifest in "mere shows of seeming pure." Just as Cesario and Lady Macbeth suggest, innocence is partial, perceptual, relative, and superficial.

Almost all conceptions of childhood innocence, however, stem from language: born "mewling and puking," the language-less infant begins its journey into adulthood through the various rites of passage that will determine the transition from innocence to experience. ${ }^{8}$ In the matrix of development, where psychological growth is never linear, these terms of definition are nebulous. Central, of course, to understanding both infancy and innocence is language itself: not just what we say but when we learn to say it. ${ }^{9}$ In Coming of Age in Shakespeare, Marjorie Garber analyzes the complex and profound ways in which the child moves into adulthood. ${ }^{\text {IO }}$ Such rites of passage do not always occur at specific moments during puberty, rather, as Garber shows, key stages of development can occur well into adulthood, and sometimes not at all. Learning to speak, however, marks the first moment at which the infant enters into the complex world of adult interaction. ${ }^{\text {II }}$ 
In The Winter's Tale, when Paulina, desperate to elicit some semblance of humanity from Leontes, produces the baby Perdita, she declares "The silence often of pure innocence / Persuades, when speaking fails" (2.2.4O-I). It is precisely this equation of innocence and infancy that defines much of the play's moral fabric. As the corollary to the sprite in Mamillius's story, the specter that "frights" this play is a notion of childhood innocence that is condemned by Leontes - not only in his rejection of his wife and baby but in his profound imbrication of all that is destructive in the adult world - sexual jealousy, mistrust, anger, and homicide. ${ }^{\mathrm{I2}}$ Although, as Garber examines, the baby's speechlessness is permissible, valuable even as a marker of its purity, when an adult loses their speech, it is a very different matter. ${ }^{\mathrm{I}}$ We need only think of Titus Andronicus and Lavinia's mute and mutilated body, paraded onstage as a terrifying gesture of experience: so defined is she now by her ordeal that death, the most resounding silence of all, according to the play-world, is the only thing that can redeem her. A subtler link between innocence and silence can be found in certain representations of adolescent women. In The Taming of the Shrew, Lucentio's observation about Bianca, for example, that "in the other's silence do I see / Maid's mild behaviour and sobriety" records a particularly male equation of muteness with purity. ${ }^{\mathrm{I}}$

Speech, according to certain founding narratives, has always had an ambivalent relationship to moral purity. Yet, in a baby, to be speechless is appropriate and an infinite reminder of the corruption that language can bring. If, as in the adult world, the profusion of tongues can manifest in variant ways (loquaciousness, eloquence, chattering, hectoring, seducing, or "plain speaking," to name only a few), then it is easy to see how infancy, the only life stage in which the human can disingenuously remain separate from the linguistic world, becomes a receptacle for ideas of innocence. ${ }^{\mathrm{IS}}$ But perhaps unsurprisingly, Shakespeare's children are rarely babies; more interestingly, they are young people who retain a vestige of their prelinguistic selves in a postlapsarian play-world. It is precisely this dynamic that gives Shakespeare the latitude to explore the possibility of innocence in a fallen world - as brief abstracts and chronicles of their time, children stand on the threshold of contamination. Fatally, dreadfully, pulled towards the language of their own undoing, they are images of loss. This transition is central to the biblical vision of enlightenment:

But when that which is perfect, is come, then that which is in part shall be abolished. When I was a child I spake as a child: I understood as a child, I thought as a child: but when I became a man I put away childish things. 
For now we see through a glass, darkly: but then shall we see face to face. Now I know in part but then shall I know even as I am know (Corinthians I3: IO-I2).

The marginal gloss to the 1599 Geneva Bible observes, "All this must be understood by comparison." The "stammering" child of this vision is only a "part" of that perfection that is fully realized in death. Such a vision of human life understands the life stage of the child as veiled, obscured, and determined by "childish things." The transition to adulthood brings with it "worldly things which are most imperfect" but also the promise of "that heavenly and eternal life." ${ }^{\prime 6}$ Medieval and early modern primers were especially focused on the child's soul and catechistic texts repeatedly emphasized the necessity of salvation as well as the child's unique access to the language of innocence. ${ }^{17}$ This double vision of childhood - one that recognizes youth as exceptional but also limited - is fundamental to the ambivalence of innocence. Equally prescient in Shakespeare's representations of children is a sense of loss - an acute awareness that such a state is always on the threshold of its own destruction. ${ }^{\text {I8 }}$

When Hermione stands before her husband and accuser, she tells him, "You speak a language I understand not. / My life stands in the level of your dreams, I Which I'll lay down" (3.2). Hermione's observation about her husband's language reflects not only the mendacious substance of what he says but also the erratic style in how he says it. Locating his agency in "dreams" determines the extent to which Leontes has strayed from the rational faculties of reason, but it also registers a trope that the play will repeatedly return to within the context of its children. Looking into his son's eyes, Leontes declares

Sweet villain,

Most dear'st, my collop - can thy dam, may't be

Affection! - Thy intention stabs the centre.

Thou dost make possible things not so held,

Communicat'st with dreams - how can this be?

$(\mathrm{I} .2 .135-9)$

In one of the play's most notoriously opaque passages, Leontes appears to be rehearsing his fears of Hermione's infidelity, and most violently, the fear that she loves Polixenes as well as desires him. Here, however, the crux is who (or what, since it could also be Affection) is "thou" - Hermione, whom he talks of, or Mamillius, whom he talks to? The intense and troubling effects of this scene are largely created by the erratic and complex emotional registers to which it appeals. Leontes moves vertiginously between the adult and child worlds in such a way as to entirely dismantle 
their decorous divide. Moving between the trivial language of the child "Come, captain, / We must be neat" - to the sexualized world of adult anxiety - "Still virginalling / Upon his palm? - how now, you wanton calf, / Art thou my calf?" (I.2.I2I-I26) - Leontes focuses on the physical body as a site of interpretation. ${ }^{19}$ It is, it seems, Mamillius's presence here that ultimately unhinges Leontes: looking directly between the heady worlds of innocence and experience forces Leontes to confront a loss and an anguish beyond that of his wife and into the very corners of his psyche. ${ }^{20}$

Turning from the welkin eye of Mamillius to his own "hard'ning of my brows," Leontes is forced to provide an explanation for his "brow of much distraction":

Looking on the lines

Of my boy's face, methoughts I did recoil

Twenty-three years, and saw myself unbreeched, In my green velvet coat, my dagger muzzled Lest it should bite its master and so prove, As ornaments oft do, too dangerous.

How like, methought, I then was to this kernel,

This squash, this gentleman

(I.2.153-159)

His response to the perplexed Hermione is that he was thinking of his childhood. Replete with ironic invocations of a presexualized world, Leontes offers an image of himself, provoked by the image of his son, in which he was not yet in trousers and his dagger was muzzled. Presenting a portrait of a young boy whose sexuality is under repression is wholly indicative of the unstable hinterland into which Leontes has strayed. Childhood, for him, is about innocence precisely because it denies the body sexual agency - and yet, of course, he speaks from an adult world in which sexual agency has contaminated everything: "By this we gather / You have slipped since" (I.2.74-5). It is the bitter and knowing world of adulthood that supports the tension of this scene, and Mamillius stands as a foil to his father's diseased mind. As the adult world takes control of childhood memories, what it means to be innocent begins to slip from view. $^{2 \mathrm{I}}$ The phallic dagger that will "bite its master and so prove, / As ornaments oft do, too dangerous" resonates through the play as both a "childish thing" and a violent object of destruction.

It is precisely the relationship between these two states, perspectives, or conditions that gives this play its power. There is perhaps nothing more disturbing than the eruption of the adult world into that of the child's. The strange, fretful, crabbed language that Leontes uses begins quite suddenly and ferociously as he is looking upon his son: 
Go, play, boy, play - thy mother plays and I

Play too, but so disgraced a part, whose issue

Will hiss me to my grave; contempt and clamour

Will be my knell. Go play, boy, play. There have been,

Or I am much deceived, cuckolds ere now,

And many a man there is, even at this present,

Now, while I speak this, holds his wife by th'arm

That little thinks she has been sluiced in's absence,

And his pond fished by his next neighbour, by

Sir Smile, his neighbour - nay there's comfort in't

Whiles other men have gates, and those gates opened,

As mine, against their will

(I.2.185-196).

Shakespeare confronts his audience with the terrifying specter of innocence on the threshold of destruction. Interspersing his musings on sin, adultery, and betrayal with commands to the boy to "play," Leontes disturbs the very meaning of childhood games - as he compels his young son to "play," so, we are to believe here, did his mother. The very idea of play becomes contaminated by its transition into the adult world of "Sir Smile." In possibly one of the most disturbing accounts of sexual fantasy that Shakespeare would write, Leontes's prurient trawl through the "gates" that have been opened by "other men," we witness the impossibility of innocence in The Winter's Tale. Relegated from the outset to memory, it will always be a fantasy of the past of the presexualized twinning of Polixenes and Leontes; Christ-like in their ovine frolicking, and boys eternal in their ignorance of women, they exchanged "innocence for innocence" (I.2.68-9). Haunted it seems by the image of his own corruption, Leontes becomes the perpetual destroyer - he has, after all "seen the spider," and to that end, he translates innocence into contempt. Recasting his unborn baby as the serpent, he imagines it will "hiss" him to his grave. In a powerful portrait of paranoia, Shakespeare reveals a man who is hell-bent on eradicating innocence and never more powerfully so than in the idea of childhood and the body of the child.

In putting his postpartum wife on trial, Leontes allegorizes one of the central values of the play-world. Associating the body of the baby with the trial that Hermione will undergo, Emilia reports a glimpse into the Queen's imprisonment:

A daughter, and a goodly babe, Lusty, and like to live. The Queen receives Much comfort in't, says 'My poor prisoner, I am innocent as you' 
Explicitly conflating two forms of innocence (the pre-linguistic and the guiltless), Emilia's report provides a direct challenge to the male fantasy of childhood propounded by the kings at the beginning of the play. ${ }^{22}$ As both females are wrongfully condemned, the hope of innocence, its recognition as well as its celebration, is under constant duress. When the Oracle proclaims that the child is "an innocent babe," we are given a brief moment of faith in the restitution of justice and the transparency of truth: when Leontes refutes that declaration, however, we are returned to the bleak world of adult contamination. Here Leontes no longer exchanges "innocence for innocence," since the very existence of such a quality is refuted. Despite Leontes's claim to such knowledge of both childhood and purity, he fails to recognize the symbolic resonance of either his wife's plea or the body of his infant daughter. Under the auspice of jurisprudence, however, the idea of innocence is further complicated through its relationship to guilt. $^{23}$

To return briefly to the quotation with which I began the chapter, we are reminded of the relationship between "not guilty" and innocence: a relationship that the play works hard to establish. As the kings remember their childhood together - established by the play as a marker of the strength of the bond between them - Polixenes defines their childish past in these terms:

We were as twinned lambs that did frisk i'th'sun, And bleat the one at th'other; what we changed

Was innocence for innocence - we knew not

The doctrine of ill-doing, nor dreamed That any did. Had we pursued that life, And our weak spirits ne'er been higher reared With stronger blood, we should have answered heaven Boldly, 'not guilty,' the imposition cleared

Hereditary ours $($ I.2.66-74)

This vignette into the childhoods of the young princes centers on three concepts that remain fundamental to the play-world: "not guilty," "innocence," and "the doctrine of ill-doing." It is the relationships between these concepts, however, that are nuanced in association with childhood. The dreams of "ill-doing" that will haunt the play could have been cauterized, so Polixenes implies, had the young boys remained in a state of perpetual childhood - and more than this, he suggests, they could have been exempt from the "hereditary" sin of the Fall and answer heaven "Boldly, 'not guilty'." Despite the syntactical ambiguity of this phrase, the implication is that the sheer force of the children's innocence could 
have cleared the human from his fallen condition. But Polixenes's halcyon vision is conditioned by the imperatives of the adult world; despite the intimation that the young boys had a choice ("Had we pursued that life"), the qualitative terms through which he defines adulthood ("stronger blood") register growth as progressive. ${ }^{24}$ To be "higher reared" is to become guilty. Although non-specific, the doctrine of ill-doing becomes inextricably entwined with adulthood. ${ }^{25}$ Within this context, Leontes presents himself as a case study in which adulthood is revealed less as a progress and more as a watershed from innocence to sin. The phrase "not guilty" resounds in the mouths of both Polixenes and Hermione as they recall, and record, versions of innocence. But as the play reminds us, to be "not guilty" and to be "innocent" are not the same things.

The presumption of innocence is the principle upon which civil law rests (although it was not enshrined as such in English Law until the nineteenth century). ${ }^{26}$ In the Sicilian court, however, the law works to the contrary: Hermione is guilty until proved innocent. ${ }^{27}$ Yet the dynamic between guilt and innocence drives the drama and centers on the relationship between adulthood and childhood. ${ }^{28}$ From the outset of the play, we are instructed to take pleasure in the friendship of the two kings. Camillo reports, "Sicilia cannot show himself over-kind to Bohemia. They were trained together in their childhoods and there rooted betwixt them then such an affection which cannot choose but branch now" (I.I. 20-23). The horticultural metaphor is entirely appropriate since it records a language of cultivation through which the development of children was frequently explored. ${ }^{29}$ Here, the young men, quite literally, grew up together, and the images of training fruit trees suggests an environment of discipline and development in which their affection was as securely planted as themselves. But it is, of course, an ambivalent image - as the epilogue to Faustus warned us - "cut is the branch that would grow full straight"; and, as Leontes will also invoke the serpent, trees of knowledge, love, or temptation can flourish but they can also destroy. Camillo's use of the word "branch" registers this ambivalence, as it seems to mean both separate and flourish at the same time.

At the beginning of the play, however, we are encouraged to see love and childhood, devotion, and decorum as central to the values of the play-world. Moving directly from Camillo's image of the young kings, Archidamus reflects on the child: "You have unspeakable comfort of your young prince Mamillius. It is a gentleman of the greatest promise that ever came into my note" (I.132-4). Archidamus's observation that Mamillius provides "unspeakable comfort" is somewhat 
surprising since there is no indication that "comfort" is required. We are advised to remember that this comfort is "unspeakable," presiding as it does in infancy or before the fully developed linguistic world of adulthood. What the observation seems to record, however, is the boy as a vestige, a reflection even, of the young kings' youth: the comfort the young prince gives is that of the past, recursive and reassuring in its ability to manifest memories of innocence over and over again. The portrait that Camillo paints of Mamillius elaborates on this idea:

I very well agree with you in the hopes of him. It is a gallant child, one that, indeed, physics the subject, makes old hearts fresh. They that went on crutches ere he was born desire yet their life to see him a man (I.I.35-8).

Described in explicitly restorative, even purgative, terms, the child is construed as a "comfort" and one who "physics the subject." Such is the potential of the child that it is almost fetishized here: even those who were decrepit at his birth desire to see him grow into a man.

Reflections such as these reveal that it is not only the body of the child that promises some kind of salvation or hope but the process of its development, too. ${ }^{30}$ Although the rhetoric of inheritance or primogeniture is conventional, the lengths to which these men go to celebrate the idea of childhood maps out the moral landscape of the play: "If the King had no son, they would desire to live on crutches til he had one" (I.I.42-43). ${ }^{3 \mathrm{I}}$ Old age and decrepitude are nothing, it seems, when there's a child in view. The contrast between youth and age, adulthood and childhood, supports the moral vision of The Winter's Tale. ${ }^{32}$ The beginning of the play works hard to amplify the emotive memories of childhood: reflected on, created even, by adults, the idea of childhood is conditioned by loss, grief, and hindsight. The child becomes the center of the moral drama: to be a child is to live entirely within the context of your own expectations, neither wistfully nor ironically; only adults define childhood as something to be cherished, something that has been lost or condemned by growing up. ${ }^{33}$ The play's investment in the child as a site of innocence as well as futurity looks powerfully to the adult world as one of failure, contamination and tragedy. ${ }^{34}$ Despite its emphasis on repentance, the play's profoundest tragic impulse lies not only in the death of Mamillius but also in Perdita growing up.

Time, ironically, the great enemy to both youth and innocence, mitigates much of the play's tragedy since it prevents us from witnessing either death or development. When we leave the "innocent babe" on the shores of 
Bohemia, we return sixteen years later to discover her a woman. As Mamillius's death is reported, so also is the great passage of time that marks Perdita's growth. Even from the outset, the possibility of innocence is relegated to the past. The play becomes a funeral dirge to what is lost; and what is found is only ever a vestige of the past, a recursive narrative of regret played out in the various languages of mourning that the play invokes. Despite the change of key that the movement to Bohemia invites, there is an overarching sense that time can never be recovered and that which is lost can never wholly be found. Whether it is Perdita's childhood, Mamillius's life, or Hermione's youth, the lines that those sixteen years have etched on her face are testimony to Time's power to divide. All three figures register and protest their innocence: the play can never fully recover any of them, so we are left, like Paulina, with one eye looking forward and the other behind us.

By the time that Shakespeare wrote The Winter's Tale, however, he had already explored the relationship between innocence, children, and mourning. In fact, the idea of mourning innocent children was so defining in the history of Richard III that a description of such graced the title pages of every quarto edition published in the sixteenth and seventeenth centuries. ${ }^{35}$ Unsurprisingly, perhaps, the idea of innocence is amplified in suffering or death: Ann Blake observes the ways in which poetry of the period, as well as Shakespeare's plays, frequently dwells on children as innocent in death (294). But she also notes:

in the world of Shakespeare's plays the innocence of living children is consistently felt. They may tease and become tiresome but they never practise that thoughtless cruelty, which appears in the imagery of the drama, most memorably in Gloucester's simile for the cruel gods: 'As flies to wanton boys are we to th'gods. They kill us for their sport' (4.I.37). No such boys occur in the plays: on the contrary, the children themselves are seen primarily as victims and in need of protection from adult wickedness. (294-5)

Blake's point is that Shakespeare's children are not socially or culturally representative: while the metaphor that Gloucester uses may casually invoke the insensitivity of childhood, the plays never represent it. $^{36}$ The discrepancy seems to point to a conscious effort on Shakespeare's part to strategically position children as relics of an alternative value system - not as mini adults in the making but as special creatures of exceptional morality: "perfect innocence is only possible in children." ${ }^{\prime 7}$ 
Unlike some of the children in Jacobean drama, however, Shakespeare's children are rarely singular receptacles of horrifying pity..$^{8}$ Even in Richard III, where the destruction of children serves to amplify the aberrance of adult cruelty, the young characters are portrayed as both the subjects and objects of grief. ${ }^{39}$ Suffering the loss of their father, the young princes become choric touchstones for the play's copious renditions of grief. Yet despite their pivotal role in the play's moral landscape, the children are more complexly rendered than simply pathetic vehicles of lament. ${ }^{40}$ Although there is no doubt that the characterizations of the princes well serve the narrative of Richard's monstrosity, my concerns here are more specifically focused on what innocence means in Shakespeare's drama and why children are carriers of virtue.

There are very few plays by Shakespeare in which the idea of innocence is irrelevant. When it becomes allied to children, however, the qualities and conditions of innocence change. No longer tied specifically to the status of guiltlessness, innocence in Shakespeare's children becomes dramatically resonant through forms of grief. In Richard III, the multiple murders produce an almost continual chorus of grieving women. Although the deaths of the children do not occur until well into the play, and indeed after Richard's coronation, our responses to the young princes has been well orchestrated by Shakespeare. In fact, Shakespeare seems to strain against the historical allure of their story by giving them a good deal of time onstage. Rather than write to an established narrative of these "innocent babes," Shakespeare creates two precocious children who work hard to establish themselves in the space between the adult and child worlds. There are four children who appear onstage in this play, and while Clarence's children are simply defined generically as a girl and a boy, they become tragic observers of the adult world. ${ }^{4 \mathrm{I}}$ Commenting on their grandmother's behavior, the children interpret her actions as gestures of distress and markers of grief: "Why do you look on us and shake your head, / And call us wretches, orphans, castaways, / If that our noble father be alive?" (2.2.5-7). Revealing their unstable position as the victims of adult word and action, the children seem to search for the right words to represent their situation. Lurching for an explanation as to their grandmother's grief, the children reveal themselves to be terrifying receptacles of adult manipulation. In response to her claim that they are "incapable and shallow innocents" who "cannot guess who caused your father's death," the boy responds: "Grannam, we can" (2.2.17, I8, I9). Reiterating Richard's claim that Clarence died at the King's behest and that he, Richard, "would love me dearly as his child," the conversation continues: 
воY Think you my uncle did dissemble, grannam? DUCHESS OF YORK Ay, boy.

BOY I cannot think it. (2.2.30-2)

The child's incredulity that an adult, no less a father figure, could dissemble marks the pathos of this scene. The innocence that the Duchess observes is simultaneously a mark of purity and one of ignorance. It is, of course, precisely this precarious position that condemns many of Shakespeare's most tragic figures. ${ }^{42}$ The Boy's refusal to believe that his uncle could lie registers the stage in a child's life when they believe that the world they inhabit also represents the values they are taught. The Duchess of York's observation that Clarence's children are "incapable and shallow innocents" can be iterated as accusatory or wistful, but either way it is their innocence as a state of unknowing that comes to the fore in this speech. It is precisely this tension between the adult and child worlds that Shakespeare's drama exploits. In the more fully realized characters of the young princes, however, Shakespeare develops this tension across a range of instances which each record the vertiginous descent of the child into the adult world.

Keith Thomas observes that children were "ubiquitous" (5I) in the early modern period: although this could be said of any period, they certainly seem to be everywhere in Richard III. Shortly after Clarence's children provide a commentary on grief, even to the extent that they chastise the young Duchess of York for her failure to properly lament their father's death, the Third Citizen makes the rueful remark: "Woe to the land that's governed by a child" (2.3.II). Although the sentiment is proverbial, the sheer moral force of the children in this play makes this moment ironic. To some extent, Richard himself never quite escapes his own child-like frame, condemned by his monstrous birth and in a constant war with his mother; his own retarded growth can resonate throughout this warning. ${ }^{43}$ But the actual children onstage in this play are shrewd observers of adult corruption and might well, had they been so put on, proved most royal. The scene in which the young prince converses with his uncle demonstrates the dramatic ways in which both adult and child try to define the limits of each other's understanding. Richard's observation on youth works hard to establish the young boy as naïve and innocent:

Sweet Prince, the untainted virtue if your years

Hath not yet dived into the world's deceit;

No more can you distinguish of a man

Than his outward show, which God He knows

Seldom or never jumpeth with the heart

(3.I.7-II) 
As Richard attempts to implicate others in the deaths of Edward and Clarence, the idea of "untainted virtue" becomes a form of failure as well as protection. The young prince is unable, so Richard suggests, by virtue of his innocence, to interpret the adult world. Yet, in a piercing deflation of Richard's sermon, the prince declares: "God keep me from false friends, but they were none" (3.I.I6). The prince is fully aware of Richard's perfidy, but the dialogue that Shakespeare creates here dramatizes, with searing insight, the powerlessness of the child who is forced to live in an adult world without the adult apparatus to control it. Briefly reverting to the language of the child by calling Hastings a "slug" (3.I. 22) for being late, the prince is characterized as belonging to the dreadful transitional space between the adult and child the "standing water between boy and man." 4

This dynamic is amplified a little later in the scene when the young York asks for Richard's dagger, "And being but a toy, which is no grief to give" (3.I.II4). The pun on "toy" as both trifle and plaything is developed by the two characters through extending the conceit through terms of "light" and "heavy." Here the pun itself becomes a metaphor for the disjunction between the understanding of the child and the adult, as both characters interpret and use - their words differently. The tension between light and heavy resonates through the scene as we witness Richard make "light" of the young boy whom he will soon have killed. In this way, history hangs heavy in this scene, as do the hearts of the audience. Buckingham delights in the double-meanings that abound here - "With what a sharp, provided wit he reasons! / To mitigate the scorn he gives his uncle / He prettily and aptly taunts himself' - but despite his best efforts, the vulnerability of the child is never more pronounced than when he is playing on the adult stage. Ultimately, of course, the corruption of this adult world cannot withstand the objectified innocence of the child, and so Buckingham assumes that "this little prating York" has been prompted by his mother. Here the idea of the child reverts to type as an "ape" or mimic who can copy or reproduce adult narratives but without adult understanding. It is exactly this function that reveals the child's vulnerability and defines their innocence. The more pejorative form of innocence in this period records the term as ignorance; and yet such ignorance need not be reviled when it absolves the young body from knowing corruption. ${ }^{45}$

The children's murder is anticipated in various keys - one is sounded by hesitation and anxiety; the other, by relish and commitment. Amplifying the significance of the act at every point we observe Richard instructing a child (his page boy) to enlist a hardened criminal to the deed: listening to Tyrell's appetite for death, Richard declares "Thou singest sweet music" 
and Tyrell readily agrees to the task. It is Buckingham's resistance, of course, that shows Richard to have finally gone too far. Yet it is not until we hear Tyrell's description of the lifeless bodies that the play fully and wholly acknowledges "The most arch-act of piteous massacre / That ever yet this land was guilty of" (4.3.2-3). Herod-like, Richard has destroyed the only virtue that the human can lay claim to. The detailed description of the deaths, and their subsequent effect on the murderers, is a powerful and fascinating ode on innocence:

Dighton and Forrest, whom I did suborn

To do this ruthless piece of butchery -

Although they were fleshed villains, bloody dogs -

Melting with tenderness and kind compassion,

Wept like two children in their deaths' sad stories

$(4.3 \cdot 4-8)$

Lingering over the "tender babes" "girdling one another / Within their innocent, alabaster arms," we hear how the "fleshed villains" were reduced to the state of a child by the murder. Here childishness becomes explicitly associated with tenderness, innocence, and "kind compassion" - more powerful, perhaps, is the brief glimpse that even the most abhorred of men can return to their childish selves and be, albeit briefly, tender in the presence of innocence. There is little in this description that resonates with the young princes we saw goading their uncle in the previous act; yet both instances and characterizations work hard to establish what innocence means. Where in the earlier scenes with Richard we see the children struggle to maintain their strength in an adult world, here we see their lifeless bodies, embracing each other in an act of kinship and tenderness that defies adult cruelty.

As "sweet work[s] of nature" children recall, prompt, or imagine the possibility of innocence in an adult world. Only in hindsight, however, can that vision exist - to answer heaven "boldly, not guilty" is to remember the child through the adult's knowledge of sin. At the end of Richard III, the idea of the child rests not in the ghosts of the dead princes or Clarence's girl and boy, but in those fleshed villains, who, having found their conscience lose their voice: "Thus both are gone with conscience and remorse. / They could not speak" (4.3. 20-2I). Perhaps, ultimately, it is not innocence that defines Shakespeare's children but memory and silence.

\section{Notes}

I. William Shakespeare, The Winter's Tale, ed. Stephen Orgel (Oxford: Oxford University Press, 1996): 3.2.2I-3I. All subsequent references are to this edition. 
2. According to Catherine Belsey, "The play represents childhood as later generations would come to know it: innocent, playful, disarming and, above all, vulnerable." Shakespeare and The Loss of Eden: The Construction of Family Values in Modern Culture (Basingstoke: Palgrave Macmillan, 1999): IO2.

3. I chose to start this essay with The Winter's Tale rather than follow the chronological order in which Shakespeare wrote these plays, because I would like to begin by assessing the complexities of the idea of innocence as a legal, spiritual, cultural, and psychological judgment in order to avoid any preemptive associations with pathos in Richard III.

4. Ralph Houlbrooke, English Family Life I576-I7I6 (Oxford: Basil Blackwell, 1989): 137-49. Houlbrooke includes a number of letters and diary entries, all of which focus on accidents, illness, and the anxiety of what might or has befallen their children. See also Keith Thomas, "Children in Early Modern England," Children and their Books: A Celebration of the Work of Iona and Peter Opie, ed. Gillian Avery and Julia Briggs (Oxford: Clarendon Press, 1989): 45-77 (47); and Lawrence Stone's remark that "this history of childhood is ... the history of how parents treated children" is found in The Past and The Present Revisited (Abingdon: Routledge, 1987): 324.

5. In fact, a survey of early modern texts on and records of infanticide recount the deed in most histrionic terms. One such description lingers on the "bloody and heavie subject" of the murder of children, which should "have been tenderly laid and lovingly looked unto." The Bloody Mother, or the Most Inhume Murders, Committed by Jane Hattersley upon Divers Infants (London, I610): A2v, A3v. I have modernized the spelling.

6. Ilana Krausman Ben-Amos observes the ambivalent ways in which children could be portrayed as both virtuous and profane in Adolescence and Youth in Early Modern England (New Haven: Yale University Press, 1994): I2-I4. Bethany Packard describes how "sixteenth and seventeenth century children could be described as both innately innocent and sinful, as lacking reason yet skilfully imitating it" in "Richard III's Baby Teeth" Renaissance Drama 4I (2013): IO7-29 (IIO).

7. William Shakespeare, The Narrative Poems, ed. Maurice Evans (Harmondsworth: Penguin, 1989): II2, 11. 99-IO5.

But she, that never coped with stranger eyes,

Could pick no meaning from their parling looks,

Nor read the subtle-shining secrecies

Writ in the glassy margents of such books:

She touch'd no unknown baits, nor fear'd no hooks;

Nor could she moralize his wanton sight,

More than his eyes were open'd to the light

As Kerrigan shows, Lucrece's innocence is directly equated with her vulnerability. Such an idea of innocence is profoundly troubling, of course, as it is something to be both desired and feared. Jon Kerrigan, "Keats and Lucrece," Shakespeare Survey 4I (1989): IO3-I8. 
8. For the early moderns, childhood innocence was a complex concept. Depending on whether you subscribed to an Augustinian view of children or a Puritan view, the child was generally considered to have been born sinful or to have had a natural predilection for sin. Many of the narratives of the sinful child are constructed to emphasize the point at which the young person sought redemption, but there is no doubt that Christian people were divided on the extent to which the child represented innocence and/or sin. There are notable exceptions to the child's innocence. Carol Chillington Rutter's essay on Macbeth reminds us of the problems of crime committed by children, most specifically murder. See "Remind Me, How Many Children Had Lady Macbeth?" Shakespeare Survey: Macbeth and Its Afterlife 57 (2004): 38-54.

9. Thomas Thomas's Latin/English dictionary describes infantia in the following terms: "infancie, babeship, childhood: also foolishness, lacke of utterance, lack of eloquence or grace to tell his tale" (Cambridge, 1587 ). As this definition implies, it is not just the acquisition of speech that defines the development into adulthood but also the eloquence and grace of expression.

Io. Marjorie Garber, Coming of Age in Shakespeare (New York: Routledge, 1997): 106.

II. "By its nature a nursery rhyme is a jingle preserved and propagated not by children but by adults, and in this sense it is an "adult" rhyme." Iona and Peter Opie, The Lore and Language of Schoolchildren (Oxford: Oxford University Press, 1959): 2I.

12. Carol Chillington Rutter discusses productions of the play in which the idea of childhood, as both a loss and an anxiety, becomes a visual conceit in performance. Shakespeare and Child's Play: Performing Lost Boys on Stage and Screen (Abingdon: Routledge, 2007): 96-153.

13. On Macbeth, for example, Garber writes that after the murder of Duncan, the hero is reduced to a "sequence of apositives": "For a moment Macbeth is reduced to 'infancy', that is, to virtual speechlessness; and as Cleanth Brookes long ago pointed out, it is as a child that he is treated by his wife from this time forward." Coming of Age in Shakespeare: 106.

I4. It is, perhaps, precisely this act of infantilization that eroticizes adult women in the male imagination. See Jennifer Higginbotham, The Girlhood of Shakespeare's Sisters (Edinburgh: Edinburgh University Press, 2013): 20-68 for an exploration of speech and femininity; and Deanne Williams, Shakespeare and the Performance of Girlhood (Basingstoke: Palgrave Macmillan, 20I4): esp. 45-9. See also Jenny C. Mann, Outlaw Rhetoric: Figuring Vernacular Eloquence in Shakespeare's England (Ithaca: Cornell University Press, 2012): II9-45; and Williams, Shakespeare and the Performance of Girlhood: 2I-5I.

I5. As Garber writes, however, "To learn to speak well, and to communicate one's meanings, is to attain successful maturity in both a dramatic and psychological sense." Coming of Age in Shakespeare: 92. Although Shakespeare may equate "full humanity "with "the proper use of speech," it is not a prerequisite of innocence. 
I6. Quotations are from the marginal gloss to Corinthians I3:I2.

17. Daniel T. Kline also notes the importance of courtesy texts, which "provided the behavioural and moral guidelines that were thought to be necessary for a child's eventual success, whether it be marriage or serving in a noble household." See Kline, “'That child may doon to fadres reverence': Children and Childhood in Middle English Literature," The Child in British Literature: Literary Constructions of Childhood Medieval to Contemporary, ed. Adrienne Gavin (Houndmills, Basingstoke: Palgave, 2012): 2I-37 (30).

18. In King John, the death of Arthur is registered in terms that symbolize profound national and historical loss: "The life, the right, and truth of all this realm / Is fled to heaven; and England now is left / To tug and scramble" (4.3.I44-6). The Norton Shakespeare, 2nd edition, ed. Stephen Greenblatt, Walter Cohen, Jean E. Howard, and Katharine Eisaman Maus (New York: Norton, 2008). All references to Shakespeare are to this edition unless otherwise stated.

19. On the point of the body as a burden of proof, see Holger Syme, Theatre and Testimony in Shakespeare's England (Cambridge: Cambridge University Press, 20I2): 205-5; and Lorna Hutson, The Invention of Suspicion: Law and Mimesis in Renaissance England (Oxford: Oxford University Press, 2007).

20. For Ann Blake, Mamillius's "role is to embody that state of sexual innocence which Leontes and Polixenes so insist on in their conversation about their youth when they were "pretty lordings." See Blake, "Children and Suffering in Shakespeare's Plays," The Yearbook of English Studies 23 (1993): 293-304 (300).

2I. P. B. Erickson discusses the gender relations in the play within the context of certain social codes, especially male gift giving and "female bounty": "These two structures of giving are illustrated by the two structures of innocence in which they originate." "Patriarchal Structures in The Winter's Tale," PMLA 97 (1982): 819-29 (820). According to Erikson, these two structures of innocence are friendship and the birth of Perdita.

22. In fact the many definitions of innocence in this period tend to conflate the idea of "puritie," associated with children, and "unguiltinesse, harmlessness," associated with sin or criminality. Cf. Randle Cotgrave, A Dictionary of the French and English Tongues (London, I6II).

23. Etymologically, the term "innocent" derives from the Latin prefix in as an expression of negation and the present participle of nocère, meaning to hurt or injure.

24. Polixenes also refers here to the Galenic view of life stages in humors, where the infant begins its life in the blood humor and the youth in the red choler, which corresponds to intemperance, passion, and fiery temper as well as strength. See Ilana Krausman Ben-Amos, Adolescence and Youth in Early Modern England (New Haven and London: Yale University Press, 1994): I6-19.

25. In a fragment of a torn manuscript, a poem begins, "From her childhood I fynde that she fled," which seems to narrate the story of a young girl who is 
characterized as having deserted her childhood when she discovered men, and, by implication, sex. British Library Tract supplement/ A3:2 [26].

26. There is, in fact, some debate as to whether this is the case since there is no record of the presumption of innocence in any constitutional proceeding prior to the nineteenth century. See also Barbara J. Shapiro's "Beyond Reasonable Doubt: The Evolution of a Concept," Fictions of Knowledge: Fact, Evidence, Doubt, ed. Yota Batsaki, Subha Mukherji and Jan-Melissa Schramm (Basingstoke: Palgrave, 2012): 19-39.

27. On this point, see Ian Maclean, Interpretation and Meaning in the Renaissance: The Case of Law (Cambridge: Cambridge University Press, 1992): 201.

28. For Subha Mukherji, however, the question of "proof" in the play emerges from the relationship between artistic and legal proof: "The productive uncertainty of plot-making and the profitable uncertainty of faith form a strange alchemy between theology and theatre, but one that requires the audience to invest their trust with their eyes open." Mukherji, "Trying, Knowing and Believing: Epistemic Plots and the Poetics of Doubt," Fictions of Knowledge: 84-109, (98).

29. See Rebecca Bushnell, A Culture of Teaching: Early Modern Humanism in Theory and Practice (New York: Cornell, 1996); and Charlotte Scott, Shakespeare's Nature: From Cultivation to Culture (Oxford: Oxford University Press, 2014).

30. John Dod and Robert Cleaver describe children who have been brought up "godly" as "a special protection and defence to their parents." A Godlie Forme of Household Government: For the Ordering of Private Families, according to the Direction of God's Wordes (London, 1612): Q4r. See also Packard, "Richard III's Baby Teeth": III.

3I. Erickson understands this representation of the male child entirely within the context of the play's patriarchal structure in which the "mirroring of the father in the son provides the basis for the transmission of property, values and the self." "Patriarchal Structures in The Winter's Tale": 82I. Robert W. Reeder takes this argument further when he claims that the play is preoccupied with male procreation and the transmission of both power and property through the reproduction of a male heir. "Siring the Grandchild in The Winter's Tale and The Fawn" SEL 48 (2008): 349-7I.

32. As Blake comments, "Children as a cure for melancholy and even a palliative to thoughts of death is a view of progeny that goes beyond the Sonnets' argument that children, like fame, offer a kind of immortality." "Children and Suffering in Shakespeare's Plays": 301.

33. Neil MacCormick examines the concept of children's rights as a test case for theories of moral and legal duties in "Children's Rights: A Test-Case for Theories of Right," Legal Right and Social Democracy: Essays in Legal and Political Philosophy (Oxford: Clarendon Press, 198I): 154-66.

34. In Erasmus's conduct book, The Civilitie of Childhood (London, 1560), the expectations placed on the child are entirely commensurate with the adult world. Here Erasmus reminds us that children must contain their bodies and 
their tongues; they must not look adult's directly in the eye but lower their eyes slightly; they must keep their noses and faces clean; they must neither fart nor belch nor ever repeat anything they might overhear at the dinner table. Such instructions reproduce adult values through the containment of the child's body. At no point does Erasmus give the child any special or exceptional understanding.

35. All the quarto editions published between 1598 and I634 advertise "the pitiful murther of his innocent nephewes" and an anonymous version of the play, published in 1594, declares "the smothering of the two young princes in the tower" on its title page. Shakespeare's title pages were not unique in publishing Richard's infamy in this way: Thomas Wincoll publishes his version as Plantagenet's Tragicall Story, or the Death of King Edward IV: With the Unnatural Voyage of Richard the Third through the Red Sea of His Nephews Innocent Blood to His Usurped Crowne (London, I649), a resonant moment, of course, to describe usurpation in these terms.

36. See also Keith Thomas, "Children in Early Modern England": 5I. Anthony Hammond describes the young prince, York, in Richard III as "a most thoroughly dislikeable brat." King Richard III, The Arden Shakespeare, 2nd Series, ed. Anthony Hammond (London: Thompson, I988): III.

37. Blake, "Children and Suffering in Shakespeare's Plays": 30I. See also R. S. White, Innocent Victims: Poetic Injustice in Shakespearean Tragedy (London: Althone Press, 1986): 46. Though somewhat dated now in the accuracy of its portrayal of early modern social history, Philippe Aries is the first social historian to observe the ways in which children were presented as miniature adults in this period in Centuries of Childhood, trans. Robert Baldick (London: Jonathan Cape, 1962): I28. Catherine Belsey develops this thesis in Shakespeare and the Loss of Eden: 85-I27. For a revisionist survey of concepts of childhood, see Linda A. Pollock, Forgotten Children: Parent-Child relations from 1500 to 1900 (Cambridge: Cambridge University Press, 1983): 96-I28.

38. Blake observes that Shakespeare's portrayal of children changes from play to play while Marston and Fletcher, for example, "merely display children in pathetic cameos." "Children and Suffering in Shakespeare's Plays": 300.

39. Heather Dubrow's Shakespeare and Domestic Loss: Forms of Deprivation, Mourning and Recuperation (Cambridge: Cambridge University Press, 1999) focuses on the death of parents, rather than children, although she notes, wryly perhaps, that "Shakespeare's representations of the princes in Richard III only a few years before [A Midsummer Night's Dream] and Macduff's son and Mamillius later in his career demonstrate that he had a good line in the pathos of imperilled children: any Hollywood agent worth his swimming pool would have insisted that the playwright exercise those skills again by realising the changeling in a dramatic character" (I5O).

40. Garber identifies the murder of the princes with a seismic shift in Richard's characterization - as well as his abilities to succeed. Here she notes a relatively linear pattern in Richard's failure to thrive, which reveals itself ultimately before the battle of Bosworth: "Once the master of persuasion, Richard has 
difficulty sustaining his language the length of a line. His telling verbal ambiguities have been replaced by a debilitating ambiguousness in his sense of self." Coming of Age in Shakespeare: 105. Packard takes this further in her exploration of the play where she observes the relationship between child, speech and destruction in the perilous/parlous dynamic that accompanies the representations of the young princes.

4I. John Jowett notes that the two pairs of children were probably played by the same actors. Richard III, ed. John Jowett (Oxford: Oxford University Press, 2000): 217. All subsequent references to this play are to this edition.

42. Desdemona is, of course, the arch example of a character who is simultaneously condemned by her innocence and her incredulity. It is perhaps no coincidence that the scene before her murder represents her at her most childlike.

43. For an examination of Lacanian theories of development, see particularly Marjorie Garber's Shakespeare's Ghost Writers (Methuen, 1997): esp. 37-68.

44. Twelfth Night: I.5.I45.

45. The last of Middleton's Six Snarling Satyres is the "Wise Innocent" which presents an often opaque debate between the fool (the innocent) and the satirist, Micro-Cynicon (London, I599): Sig. fol. 20-I. Wendy Wall's understanding of the poem as a trial has particular resonance within the context of this essays' exploration of innocence: "The reversals that have hovered around the other satires become the subject of the last poem, where a supposed critique of wise (foolish) innocence becomes the satirist's own trail", Thomas Middleton, The Complete Works, eds. Gary Taylor and John Lavagnino (Oxford: Oxford University Press, 2007) 